\title{
A FALÊNCIA do IDEAL ASCÉTICo E A BUSCA POR SENTIDO NA EXISTÊNCIA COMO EIXO DA GENEALOGIA DA MORAL
}

\author{
[THE BREAK OF THE ASCETIC IDEAL AND THE SEARCH FOR MEANING IN EXISTENCE AS AN \\ AXIS OF THE GENEALOGY OF MORALS]
}

\author{
Sérgio Gonçalves Ferreira * \\ Universidade Católica de Pernambuco \\ Marcus Túlio Caldas ** \\ Universidade Católica de Pernambuco
}

\begin{abstract}
Resumo: O presente artigo assume como hipótese que a análise do sentido da vida é fundamental na filosofia nietzschiana. A argumentação baseia-se no estudo da Genealogia da moral, particularmente no exame da terceira dissertação deste livro, mas registrando que as duas primeiras dissertações constroem as bases que vão permitir a ênfase de Nietzsche na questão do sentido da vida. Nossa linha reflexiva segue a do filósofo, partindo como ele da crítica aos ideais ascéticos e colocando o olhar nos comportamentos dos artistas, dos filósofos, dos sacerdotes e dos cientistas. Chega ao conceito do niilismo, que denota o desespero do ser humano, ao não encontrar resposta para a aparente falta de objetivo na sua vida. No niilismo a vontade de verdade esbarra no vazio, levando Nietzsche a constatar a motivação para a existência do ideal ascético, qual seja, a razão está no afastamento que esse ideal promove do vácuo existencial, o qual, para o filósofo, na nossa percepção, representa o temor humano fundamental.
\end{abstract}

Palavras chave: Genealogia da moral; sentido da vida; ascetismo; niilismo; além do homem
ABSTRACT: This article assumes that meaning of life analysis is fundamental in Nietzschean philosophy. The argument is based on the study of the On the Genealogy of Morality, particularly in third essay examination of the book, but noting that the first two essays build the bases that will allow Nietzsche's emphasis on the meaning of life. Our reflexive follows Nietzsch philosopher line, like him departing from the ascetic ideals and focusing artists, philosophers, priests and scientists behaviors. $\mathrm{He}$ arrives at the concept of nihilism, which denotes the human despair, by not finding an answer to apparent life purpose lack. In nihilism the will to truth comes up against emptiness, leading Nietzsche to verify the motivation for the existence of the ascetic ideal. The reason is in the distance that this ideal promotes from the existential vacum, which, for the philosopher, in our perception, represents the fundamental human fear.

KEYWORDS: On the Genealogy of Morality; meaning of life; asceticism; nihilism; over men

\section{ApresentaÇÃo}

osso estudo toma como eixo a Genealogia da moral. Sobre essa obra
levantamos a seguinte hipótese: a sua ideia central é a questão do sentido da vida. Especificando, na nossa perspectiva a vontade humana de ter um objetivo na existência é a abordagem maior da terceira e última dissertação desse livro. Ademais,

* Doutorando em Psicologia pela Universidade Católica de Pernambuco (UNICAP). E-mail: sergio@guimaraesferreira.com.br. ** Médico psiquiatra, doutor em psicologia pela Universidade de Deusto - Espanha, professor do curso de psicologia, graduação e pós-graduação, na Universidade Católica de Pernambuco (UNICAP).E-mail:marcus_tulio@uol.com.br. 
percebemos nas duas primeiras dissertações a criação de bases, as quais permitem constatar, na secção final, que Nietzsche coloca o seu olhar na reflexão sobre o nosso sentido existencial. Para nós isso fica claro num texto significativo, o qual o autor coloca tanto no começo, como ao final da terceira dissertação:

Porém, no fato de o ideal ascético significar tanto para o homem se expressa o dado fundamental da vontade humana, o seu horror vacui [horror ao vácuo]: ele precisa de um objetivo - e preferirá ainda querer o nada a nada querer. Compreendem?... Fui compreendido? "Absolutamente não, caro Senhor!" Então comecemos do início (GM, III, 1).

Dada a importância desse trecho no nosso raciocínio, que inclusive soa para nós como se fora um aforismo, vamos guardá-lo e trazê-lo de volta na conclusão. Adicionalmente, na citação acima, observa-se um importante conceito desenvolvido por Nietzsche, que é o de ideais ascéticos ${ }^{1}$. Destaca-se que o filósofo, tendo em mente a questão ascética, faz a sua crítica aos valores ocidentais que reprime a sensualidade e louva a antinatureza ${ }^{2}$ da castidade. Nessa perspectiva, ele inicia as reflexões da terceira dissertação observando que os ideais ascéticos têm significados variados, dependendo do grupo de pessoas que são tomadas por eles. E Nietzsche, tendo em mente uma gama de significados para o ascetismo, como se verá adiante, aborda o tema colocando a sua visão perspectivista nos artistas; nos filósofos e eruditos; nas mulheres; nos fisiologicamente deformados ${ }^{3}$; nos sacerdotes; e, nos santos.

\section{O ASCETISMO ENTRE OS ARTISTAS E OS FILÓSOFOS}

Para desenvolver sua noção de ascetismo o filósofo toma como referencial de partida os dois referidos pontos: sensualidade e castidade. Neste exame, inicialmente, o filósofo utiliza a maneira de ser do músico Richard Wagner, que mudou ao longo da vida, e depois o contexto da filosofia de Schopenhauer, a qual, com o passar dos anos, foi perdendo a admiração de Nietzsche. No nosso entendimento, inclusive, a apreciação sobre esses dois personagens aparece como se fosse aquilo que, na atualidade, em metodologia científica, se considera como estudo de caso.

Assim, o filósofo nota que Wagner, em sua maturidade, não na velhice, tinha a castidade como um valor que estava adequado à sensualidade - "Pois entre castidade e sensualidade não há oposição necessária; todo bom casamento, todo verdadeiro caso amoroso está além dessa oposição" (GM, III, 2). Nessa citação percebemos que o filósofo está afirmando, sobre o músico, que ele antes de envelhecer era adepto das ideias de Lutero, haja vista que o monge fundador do protestantismo permitiu que os seus pregadores se casassem e tivessem uma vida sexual ativa. De outro modo, foi a oposição entre a sensualidade e a castidade que o filósofo criticou de forma dura, percebendo-a em Wagner, quando o artista chegou à velhice. É a castidade numa visão comum, como repulsa a sensualidade: "a mais crua forma da antinatureza do ideal ascético" (GM, III, 3). Nietzsche se contrapõe ferozmente a castidade (num casal) e ao celibato (decisão pessoal), registrando essas concepções como coisa de desgraçados suínos.

Refletindo sobre a mudança de Wagner, entre a maturidade e a velhice, Nietzsche conclui sobre todos os artistas, quanto ao que significa os ideais ascéticos para eles: "nada absolutamente!... Ou tantas coisas, que resultam em nada! Eliminemos de imediato os artistas: eles estão longe de se colocar independentemente no mundo, e contra o mundo, para que as suas avaliações, e a mudança delas, mereçam em si interesse!" (GM, III, 5). Com isso, o autor da obra genealógica diz que os artistas 
sempre dependem do espírito da época ou de alguém para realizar as suas criações. Ou seja, eles não têm independência e autoridade sobre si, logo, os trabalhos que fazem estão acima deles, fora dos seus domínios - é como se as obras tivessem vidas próprias": "o melhor é separar o artista da obra, a ponto de não tomá-lo tão seriamente como a obra. Afinal, ele é apenas precondição para a obra, o útero, o chão, o esterco e o adubo no qual e do qual ela cresce" (GM, III, 4).

De outro modo, para o pensador do martelo a concepção das ideias é basicamente da competência dos filósofos. Foi assim que Nietzsche questionou: "E com isso chegamos à questão mais séria: o que significa um verdadeiro filósofo render homenagem ao ideal ascético, um espírito realmente assentado em si mesmo [...] que tem coragem de ser ele mesmo, que sabe estar só, sem esperar por anteguardas e indicações vindas do alto?" (GM, III, 5).

Nietzsche tomou Schopenhauer como paradigma no desenvolvimento da sua concepção sobre os filósofos, de forma semelhante ao que fez com Wagner, em relação aos artistas. Nesse contexto há que considerar, também quanto a Schopenhauer, que Nietzsche assimilou duas visões diferentes sobre este pensador. De fato, inicialmente ele exerceu grande influência na produção nietzschiana. Porém, posteriormente, Nietzsche passou a ser um crítico dele, por considerá-lo um filósofo negativista, que não procurava outra perspectiva que não fosse o pessimismo:

Sobretudo não subestimemos o fato de que Schopenhauer, que tratava realmente como inimigo pessoal a sexualidade (incluindo seu instrumento, a mulher, este instrumentum diaboli [instrumento do diabo]), necessitava de inimigos para ficar de bom humor; o fato de que amava as palavras furiosas, biliosas e de cor escura; de que se enraivecia por enraivecer, por paixão; de que teria ficado doente, teria se tornado um pessimista ( - o que não era, por mais que o desejasse) sem os seus inimigos, sem Hegel, sem a mulher, a sensualidade e toda a vontade de existência, de permanência (GM, III,7).

A forma de Schopenhauer encarar a vida, sem levar em consideração o lado da alegria, de outro modo, apenas focando a tristeza, o tédio e a dor na existência humana, é filosoficamente destacada por Nietzsche com o propósito de analisar a questão da estética, da beleza, bem como tratar dos sentimentos envolvidos nessas temáticas. Assim, na percepção nietzschiana, Schopenhauer via o belo simplesmente como tendo potencial para moderar o tédio e acalmar os indivíduos, ou melhor, essa seria a principal função da beleza - uma visão na qual a sensualidade na estética estaria subtraída, para que as pessoas apenas admirassem o belo, sem nenhuma sensibilização pelo lado sexual, sem ficarem mexidas e nem excitadas: "Sobre poucas coisas Schopenhauer fala de modo tão seguro como sobre o efeito da contemplação estética: para ele, ela age precisamente contra o interesse sexual [...] nunca se cansou de exaltar esta libertação da 'vontade' como a grande vantagem e utilidade do estado estético" (GM, III,6).

Ora, o autor genealógico pensa exatamente o oposto, examinado a questão sob a perspectiva artística ao criar o belo, afirmando que nessa criação há interesse na sensibilização do espectador. Ademais, até ironiza uma posição diferente da sua: "É certo que nossos estetas não se cansam de argumentar [...] que sob o fascínio da beleza podemos contemplar 'sem interesse' até mesmo estátuas femininas despidas, então será permitido rir um pouco à sua custa" (GM, III,6).

De fato, Nietzsche aproveita a perspectiva de Schopenhauer sobre a beleza estética na arte, justamente criticando essa possibilidade que o filósofo pessimista levanta, ao retirar das obras a visão da sensualidade (visão que para este é como uma tortura), para voltar a sua questão de fundo: “"que significa para um filósofo render 
homenagem ao ideal ascético?' eis aqui ao menos uma primeira indicação: ele quer livrar-se de uma tortura -" (GM, III,6).

Nietzsche fez na Genealogia da moral um breve exame histórico e mostrou que a filosofia conseguiu se desvincular dos pensamentos e imposições torturantes das tradições, considerando para tanto que o ideal ascético criou tais condições, nas quais a reflexão filosófica pode ocorrer com rigor, justamente à base do ascetismo, mas, de outro modo, sem se prender a dogmas religiosos ou concepções divinas. Ao contrário, com o pensador indo em busca da razão, por meio do constante questionamento sobre as coisas que são vistas no mundo. Esse espírito filosófico, de dúvida, foi crescendo ao longo da história, até chegar à era moderna, onde se exacerbou:

Violentamos a nós mesmos hoje em dia, não há dúvida, nós, tenazes, quebranozes da alma, questionadores e questionáveis, como se viver fosse apenas quebrar nozes; assim nos devemos tornar cada vez mais passíveis de questionamento, mais dignos de questionar, e assim mais dignos talvez - de viver?... (GM, III,9).

Na nossa percepção essa citação é digna de nota porque ressalta a importância que Nietzsche atribui aos filósofos, como homens que podem mudar o curso da história, desde que sejam questionadores, fujam do dogmatismo e da tradição conservadora.

\section{O PAPEL DO SACERDOTE ASCÉTICO E O ALÉM COMO SENTIDO PARA OS SOFREDORES}

Nietzsche admitiu que um pensador filosófico é aparentado com o sacerdote ascético, com a conexão entre eles estabelecida no gosto de meios que permitam alcançar condições excelentes para pensar, a exemplo de um lugar reservado, livre de perturbações, de reuniões e paixões mundanas, enfim, o objetivo comum é encontrar formas de vida que facilitem reflexões profundas. Todavia, não mais do que isso - não mais do que a vontade de ter condições propícias para a introspeção. Entrementes, aqui há a separação, haja vista que o verdadeiro filósofo, além de desejar pensar sem dificuldades, deveria também almejar a liberdade, vendo os fenômenos sob várias perspectivas, de forma rígida e livre de dogmas.

Já o sacerdote tem no ideal ascético o propósito da sua vida: "não apenas a sua fé, mas a sua vontade, seu poder, seu interesse. Seu direito a existência se sustenta ou cai com esse ideal" (GM, III,11). Para o autor da Genealogia da moral essa fé ascética é completamente afastada da vida na Terra, da existência em meio a natureza. Ao contrário, o ideal dos ascéticos concebe outra vida, fora deste mundo concreto. Além do mais Nietzsche observa, em relação à vida aqui e agora, que o sacerdote ascético coloca:

[...] uma existência inteiramente outra, a qual exclui e à qual se opõe, a menos que se volte contra si mesma, que negue a si mesma: neste caso, o caso de uma vida ascética, a vida

vale como uma ponte para essa outra existência. O sacerdote trata a vida como um caminho errado, que se deve enfim desandar até o ponto onde começa; ou um erro que se refuta - que se deve refutar com a ação: pois ele exige que se vá com ele, e impõe, onde pode, a sua valoração da existência (GM, III,11).

Nietzsche pontua que se verifica, de forma espantosamente espalhada e generalizada, essa forma ascética de perceber a vida e de existir, e isso no mundo como 
um todo. Ou seja, repete-se na face da Terra, entre as várias concepções religiosas, com os seus sacerdotes ascéticos presentes em todas as partes do globo. Com essa visão o filósofo questiona: como pode ser tão difundida uma forma de viver que vai contra a vida, a sua própria geração e o prazer de viver? Com efeito, para ele realmente é um contrassenso ser: "contra o florescimento fisiológico mesmo, em especial contra a sua expressão, a beleza, a alegria; enquanto se experimenta e se busca satisfação no malogro, na desventura, no fenecimento, no feio, na perda voluntária, na negação de si, autoflagelação e autossacrifício" (GM, III,11).

Nietzsche continua com a sua perplexidade, ressaltando que o sacerdote ascético adota um artifício inteligente para fazer a negação da vida natural na Terra. Assim, é como se esta vida terrena fosse uma vida de ilusão, então, a verdadeira vida estaria fora do aqui e agora. Dessa forma, o sacerdote ascético constrói sua doutrina acreditando que o verdadeiro mundo está longe da natureza. De outro modo, este atual mundo concreto é que seria um sonho, tempo e espaço passageiro onde não é bom nele se considerar realizado, mas, sempre buscar a felicidade fora desta vida: "Recusar a crença em seu Eu, negar a si mesmo sua 'realidade' - que triunfo!” (GM, III,12).

O filósofo aprofunda a crítica ao sacerdote ascético mostrando que ele incentiva o adoecimento humano, ao negar a imanência e pregar o afastamento da vida terrena. Ademais, porque usa a doença para conseguir manter o domínio sobre os membros do rebanho, fazendo os indivíduos ficarem dependentes dele. Ao mesmo tempo o sacerdote vai fortalecendo os vínculos com essas pessoas enfraquecidas, bem assim, com isso ele vai estendendo sua ação e criando condições para ampliar o número de sofredores. Dessa forma, o método explorado pelo sacerdote ascético tanto facilita o aumento, como a manutenção de doentes, haja vista que reforça nos adoecidos a relação com o sofrimento. Seja como for, ele visa, mesmo, aquilo que é doente e ruim:

"Alguém deve ser culpado de que eu esteja mal" - esta maneira de raciocinar é
comum a todos a todos os doentes, tanto mais quanto lhes for desconhecida a
verdadeira causa do seu mal-estar, a fisiológica (- ela pode ser encontrar-se,
digamos, numa enfermidade do nervus sympathicus, numa anormal secreção de
bílis, numa pobreza de sulfato e fosfato de potássio no sangue, em estado de
tensão do baixo-ventre que impedem a circulação do sangue, ou ainda numa
degeneração dos ovários etc.). Os sofredores são todos horrivelmente dispostos e
inventivos, em matéria de pretextos para seus afetos dolorosos; eles fruem a
própria desconfiança, a cisma com baixezas e aparentes prejuízos, eles revolvem
as vísceras de seu passado e seu presente, atrás de histórias escuras e
questionáveis, em que possam regalar-se em uma suspeita torturante, e intoxicar-
se do próprio veneno de maldade-(GM, III,15).

O sacerdote verifica o resultado ou efeito do veneno autoaplicado pelos membros do rebanho, mas procura perceber, antes, o encontro de alguma causa extraterrena, condicionando o mal nas pessoas. Não se está doente de forma acidental ou natural, haja vista que para ele sempre é uma causa suprema, sobre a qual, evidentemente, procura fazer correlações junto aos sofredores, para justificar a doença e o sofrimento. Vale observar que esse adoecimento não é tão somente mental, pode ser também uma perturbação fisiológica do organismo ${ }^{5}$, mas, seja como for, sempre se deve encontrar um culpado.

Ressalta-se que o tema abordado por Nietzsche - a questão de encontrar um culpado pelo mal, e o consequente sofrimento pessoal - é resolvido de uma forma criativa pelo sacerdote ascético, para os membros do seu rebanho: "Isso mesmo minha ovelha! Alguém deve ser culpado: mas você mesma é esse alguém - somente você é culpada de si!...'. Isto é ousado bastante, falso bastante: mas com isso se alcança uma 
coisa ao menos [...] a direção do sofrimento é - mudada" (GM, III, 15). Neste ponto, o filósofo mostra um estratagema do sacerdote, o da internalização da culpa (criando a concepção do pecado). E, analisando o sacerdote sobre essa internalização, Nietzsche diz que ele foi muito inteligente, pois a partir dessa artimanha mental as pessoas ficam culpando a si mesmas. Com isso, se obtém a vantagem de possibilitar a redução da revolta entre os próprios membros do rebanho, evitando que uns culpem os outros. Ademais, o sacerdote consegue evitar que pessoas fracas, como são os membros do rebanho, entrem em confronto com os fortes e assim venham a perecer.

De fato, pelo menos ali não serão encontrados os culpados pelas suas desgraças, haja vista que cada um internalizou o mal como advindo da sua própria culpa - logo, não tem razão para penalizar os outros. Aqui, ressaltamos que Nietzsche conseguiu nessa parte da Genealogia da moral, em termos psicológicos, adentrar em dois tópicos, bem como criticá-los: o aspecto do consolo, com a formulação de uma explicação do sofrimento por uma suposta causa superior; bem como, percebeu a transferência de culpa - decididamente a transferência para dentro de $\mathrm{si}^{6}$, criando o pecado.

$\mathrm{O}$ autor da Genealogia da moral aprofunda seu texto com a análise das atitudes do sacerdote, qual seja, sua atividade de consolador trabalhando com os afetos, aquele que mitiga os sofrimentos e alivia as tristezas. Vê essa característica nas três grandes religiões, cristianismo, budismo e hinduísmo: "em todas as grandes religiões, a questão principal sempre foi combater uma certa exaustão e gravidade tornada epidemia [...], seu remédio, pode ser procurado e experimentado tão somente no domínio psicológicomoral ( - esta é minha fórmula mais geral para o que comumente é chamado de 'religião')"' (GM, III,17).

\section{CRítica de Nietzsche aOS Cientistas}

Prosseguindo na Genealogia da moral, Nietzsche analisa o papel da ciência fazendo frente ao ideal ascético, fato que passou a ser observado com o surgimento da Era Moderna. Até então, o citado ideal reinou sem ter oposição, sem outra forma de percepção do mundo, que se contrapusesse à caminhada do sacerdote com seu ascetismo. A situação só começou a mudar com o aparecimento do conhecimento científico, iniciando uma oposição ao então absoluto predomínio da religião cristã no Ocidente: "esta ciência moderna que, como verdadeira filosofia da realidade, evidentemente crê apenas em si mesma, evidentemente possui a coragem, a vontade de ser ela mesma, e até agora saiu-se bastante bem sem Deus, sem Além e sem virtudes negadoras" (GM, III,21).

Entretanto, na sequência, o filósofo faz uma crítica severa àqueles que estão envolvidos diretamente com a ciência. Nessa direção, afirma que eles ainda não têm um ideal verdadeiro para se contrapor ao ascetismo - pelo contrário, na verdade continuam cultuando o ideal ascético: "a ciência é hoje um esconderijo para toda espécie de desânimo, descrença, remorso, despetio sui [desprezo de si], má consciência - ela é a inquietude da ausência de ideal, o sofrimento pela falta do grande amor, a insatisfação por uma frugalidade involuntária" (GM, III,23). Essas colocações de Nietzsche nos dizem que os cientistas "ainda" não tinham se libertado da influência do ideal ascético (será que já estão libertos?). Ou seja, à época observando as pessoas ligadas à ciência, é como se esses fossem uns sofredores: "que não querem confessar a si mesmos o que são, com gente entorpecida e insensata que teme uma só coisa: ganhar consciência..." (GM, III,23).

Comentando a posição do filósofo posta no parágrafo anterior, registra-se que a 
ciência a qual ele criticava era uma forma de desenvolver o conhecimento ainda acreditando no encontro de uma verdade absoluta, numa essência e num ideal perfeito. Evidentemente Nietzsche, desenvolvendo conceitos como o perspectivismo e a vontade de potência, se contrapunha a essa forma de fazer ciência, que no entender do autor da Genealogia da moral está impregnada de fé metafísica e de platonismo (c.f. GM, III, 24).

Para ele, o temor desses cientistas com uma vitória da consciência é semelhante ao temor de encontrar-se consigo mesmo. Então, ver que não existe verdade absoluta em nenhum lugar, considerando que para Nietzsche "tal" verdade é uma mera idealização do ascetismo, que nasceu na religião e continua com a ciência moderna. Nesse contexto afirma, sobre o modelo de tal ciência: "Mas o que a força a isto, a incondicional vontade de verdade, é a fé no próprio ideal ascético, mesmo como seu imperativo inconsciente, não havendo engano a respeito - é a fé num valor metafísico, um valor em si da verdade [...]" (GM, III,24).

Nós acreditamos que foi para instigar os cientistas que Nietzsche tratou-os como uns meros novos aliados do sacerdote ascético, dizendo que eles estavam baseados: "na mesma superestimação da verdade (exatamente: na mesma crença na inestimabilidade, incriticabilidade da verdade), e com isso são necessariamente aliados - de modo que, a serem combatidos, só podemos combatê-los e questioná-los em conjunto" (GM, III,25).

Tão interessante quanto o que é visto na citação anterior - o filósofo colocando os conhecimentos científico e religioso na mesma vala comum dos ideais ascéticos - é perceber o filósofo exaltando a arte, afirmando: "a arte, na qual precisamente a mentira se santifica, a vontade de ilusão tem a boa consciência a seu favor, opõe-se bem mais radicalmente do que a ciência ao ideal ascético [...]." (GM, III,25). Ora, aqui percebemos Nietzsche fazendo uma crítica que contrasta a criatividade dos artistas com a carência de inovação por parte dos cientistas do seu tempo (o apego desses à tradição e ao formalismo). Logo, o filósofo mostra um pensamento diferente sobre o mundo artístico, tomado pela vontade de criar. Ou seja, o espírito do ofício que ele exerce, faz o artista sempre estar à procura de novos caminhos, sem uma meta preestabelecida (embora por vezes seguindo a meta de terceiros ou o mero espírito de uma época).

\section{A MORTE DE DEUS, O NIILISMO E O ALÉM DO HOMEM}

Antes de voltar ao questionamento sobre o sentido da vida, que tanto inicia como finaliza a terceira dissertação da Genealogia da moral, seguindo o roteiro de Nietzsche passa-se agora pela questão do niilismo. Esse é outro tema que o filósofo procurou conceituar, alertando para o niilismo como um novo problema, que os homens podem desenvolver nas suas existências, à medida que vão identificando contradições nos dogmas, nos valores e na moralidade do cristianismo.

Sobre a gênese do comportamento niilista, Nietzsche observou que enquanto a ciência moderna foi se desenvolvendo, também cresceu o distanciamento de Deus - em outras palavras, difundiu-se o ateísmo na humanidade. Em paralelo, o homem foi se achando um ser pequeno e, mesmo, desprezível. Logo, o desprazer com a vida, até então proveniente do ideal ascético, mudava de orientação. Com efeito, passava a ser proveniente do choque que o ser humano teve ao perceber que a Terra não era o centro do universo e ele não podia, cientificamente, se julgar uma criatura privilegiada, coisa que a perspectiva religiosa, anteriormente, lhe garantia ser. $\mathrm{O}$ homem passou a se ver como um mero ente no meio de outros entes: "Precisamente a autodiminuição do homem, sua vontade de diminuir-se, não se acha em avanço irresistível desde 
Copérnico? Oh, a crença em sua dignidade, singularidade, insubstitutibilidade na hierarquia dos seres se foi -" (GM, III,25).

Para o único ser que a ciência, até o presente, percebe como capaz de filosofar, essa mudança histórica foi drástica e, ainda hoje, passados cerca cento e trinta anos dos textos de Nietzsche abordando essa questão, para muitos indivíduos continua a ser algo de difícil aceitação. Ou seja, no íntimo o homem niilista ainda não se conforma com o fato, ao que parece, de ser apenas um mero passageiro no planeta Terra e, com certeza, habitando unicamente um astro a girar no espaço, como bilhões de outros estão girando. O niilismo é o reflexo do choque que a percepção da pouca importância do homem no cosmo provoca no próprio homem, fato que termina levando pessoas ou grupos a se sentirem perdidos na vida - sumiram as certezas que o cristianismo e o sacerdote ascético transmitiam, então, em vista disso, algumas pessoas deixaram de encontrar sentido nas suas existências.

Lembrando que o poder político dos reis e a força da nobreza provinham de Deus, abençoando determinadas pessoas - que assim detinham autorização divina para governar seus súditos -, observa-se que alguns acontecimentos, do final do Século XVIII e durante o Século XIX, terminaram refletindo a redução do poder da cristandade na governança do mundo. Com efeito, o Iluminismo, a Revolução Francesa, a queda dos reinados na maioria dos países europeus, o surgimento da democracia e das eleições de governantes por meio do voto popular, foram fatos históricos que implicaram "diminuição" do poder de Deus na Terra. A essa verdadeira revolução social soma-se a revolução trazida pelas ciências naturais, que possibilitaram a contestação de concepções metafísicas e místicas presentes no cristianismo, ou seja, as pesquisas na botânica, na medicina, na física e na química, por exemplo, destronaram várias "teses" religiosas. Foi nesse contexto que Nietzsche conceituou: Deus está morto!

De fato, foi a vontade de encontrar uma "verdade" que fez o conhecimento científico avançar, mas terminou provocando a "morte de Deus" no Ocidente, o que se refletiu na queda de prestígio da Igreja e do protestantismo tradicional no ambiente cultural, a partir da segunda metade do século XIX. Entretanto, noutra perspectiva, isto foi uma verdadeira catástrofe, porque deixou muitos seres humanos atônitos ou perdidos. Nietzsche é forte nessa sua reflexão:

O ateísmo incondicional e reto [...] não está, portanto, em oposição a esse ideal, como parece à primeira vista; é, isto sim, uma das últimas fases do seu desenvolvimento, uma das suas formas finais e consequências internas - é a apavorante catástrofe de uma educação voltada para a verdade que dura dois milênios, que por fim se proíbe a mentira de crer em Deus (GM, III, 27).

Após a morte de Deus o nada, esse além vazio que dava sentido aos homens desaparece, então, resta nada de sentido. Em outros termos, aquele niilismo que se caracterizava por "querer o nada" é substituído por outro mais extremo, o niilismo da ausência de sentido.

O filósofo fez colocações levando em conta a questão espiritual ${ }^{7}$ e até desenvolveu a ideia de uma metafísica artística ${ }^{8}$. Bem como, na alegoria do seu Assim falava Zaratustra, lançou o pensamento do além do homem ${ }^{9}$. De antemão, é interessante registrar que a palavra "além" nessa expressão nietzschiana não tem nada a ver com o sentido espiritual comumente tomado na língua portuguesa, qual seja, o além como algo fora da Terra. Não, aqui em Nietzsche, pelo contrário, além quer dizer superar ou ultrapassar o homem da Era Moderna, que é niilista, preso à moral cristã, que vive sonhando e imaginado no Céu encontrar e usufruir outra vidax ${ }^{10}$. Então, o além do homem é um ser humano renovado, que para atingir os seus sonhos despreza o 
Deus metafísico e se apoia nos seus impulsos, mas, fazendo isso como uma pessoa forte, consciente e responsável.

Qualquer niilista, mesmo os que não pensam em suicidar-se, simplesmente não encontram mais sentido na vida ou deixam de querer procurar sentido, principalmente no que passam a ver como nada ou algo vazio. Com efeito, deixam para lá o "nada", não despertando o interesse dos niilistas as questões existenciais que se apresentam multidimensionais, complexas e intangíveis, pois apenas as antigas certezas postas pelas tradições (pródigas em objetos, locais, datas, textos, interditos sagrados e coisas tangíveis) possibilitavam manter ligações (religare) com fenômenos até o presente inexplicáveis pela razão humana. Para eles só a existência, ideal, de um Deus presente nas religiões era interessante, era tudo, estava completo e preenchia a vida.

\section{A TRAnSVAloraÇão dos VAlores, A VONTADE de VERDADE E A BUSCA DE SENTIDO}

Com o intuito de procurar facilitar a compreensão do nosso artigo, apresentamos a seguir uma síntese esquemática de pontos da terceira dissertação vistos até aqui, que nos auxiliam na chegada à nossa conclusão. De antemão, lembramos que o filósofo inicia sua reflexão colocando o foco no ideal ascético. Toma esse ideal como um "doador" de sentido, entretanto, se opondo frontalmente ao sentido apregoado pelo ascetismo, cujo propagador é o sacerdote. Talvez, por essa razão, como vimos apresentou outro projeto de vida, o além do homem, que vai em direção diametralmente oposta. Sintetizando o que mostramos da obra genealógica até aqui e anunciando o que virá:

- O ideal ascético é uma conceituação nietzschiana que possibilita demarcar duas formas para o ser humano viver.

- Segundo o filósofo, uma dessas formas é saudável. A outra é doente. Essa última é aquela que vive voltada para outro mundo, ou seja, sem afirmar a existência.

- O filósofo propõe que os seres humanos se concentrem e vivam plenamente a vida na Terra, enfrentando com suas próprias energias as dificuldades e tragédias deste mundo.

- Nietzsche observa que o Ocidente era niilista por querer o nada, ou seja, uma civilização que é norteada pelo além inexistente e que procura sentido no vazio, onde "vê" esse além.

- O sacerdote ascético promove tal niilismo por meio da retórica que infla o nada, prega o sentido em algo que estaria fora da Terra, além da natureza e, assim, o vazio passa a dar sentido à vida humana no mundo ocidental.

- $\mathrm{O}$ ascetismo penetrou na ciência moderna ao fazer que ela mantenha a vontade de verdade, desse modo permanece a perseguição a supostas verdades puras, perfeitas, exatas e plenas, sempre idealizadas e a serem descobertas pelos seres humanos.

- A vontade de verdade faz a ciência progredir e provoca a "morte de Deus" no mundo ocidental. Este movimento, em paralelo, também acarreta para muitos homens um sentimento de perda, de vazio - enfim, as certezas divinas derrubadas causam perturbação.

- Com a morte de Deus o antigo nada - um espaço que era preenchido pelo cristianismo e oferecia sentido às vidas humanas - se caba; logo, aparece no Ocidente um clima de "nada de sentido". Ou seja, um niilismo é substituído por outro. Aquele que queria o "nada" é convertido noutro niilismo, ainda pior, pois implica numa falta de razão para viver, a qual, inclusive, pode levar ao suicídio. 
- Neste contexto surge a proposta de Nietzsche do além do homem, pois esse ser não suporta viver sem sentido e prefere "querer o nada a nada querer", como refletiu o filósofo, logo no início da terceira dissertação da Genealogia da moral. E, nessa mesma direção, ele nos legou também o conceito de transvaloração dos valores, que é uma tentativa de dar novo sentido ao homem ocidental.

- Com efeito, a transvaloração dos valores é o esforço para empreender uma completa mudança no rumo vigente na cultura do Ocidente. Então Nietzsche propõe uma ação para fazer verdadeira inversão nos valores morais irradiados a partir da Europa, abandonando a pregação ascética do sacerdote cristão e mudando a orientação para valores que afirmem a plenitude da vida na Terra.

Relembra-se que na época que Nietzsche escrevia a religião cristã detinha proporcionalmente maior poder na cultura ocidental, com a voz das autoridades eclesiásticas impondo mais respeito do que tem na atualidade. Ademais, era menos comum as pessoas assumirem o ateísmo ou o agnosticismo, embora movimentos nesse sentido, como o positivismo, começassem a crescer. Desse modo, o sentido da vida ainda era dado de modo tácito, legal e facilmente pela tradição, com o ideal ascético. Com efeito, o niilismo era observado basicamente apenas entre aqueles que já estavam sofrendo com a ruptura das tradições e ficaram sem ter para onde apelar e se apegar. Nessa perspectiva, com o filósofo percebendo o potencial de um novo rumo para a civilização (partindo de alguns sinais de perda da importância do cristianismo no ocidente), foi que ele introduziu no seu projeto filosófico as citadas reflexões: a morte de deus, o além do homem e a transvaloração dos valores.

Entendemos que Nietzsche se contrapôs frontalmente ao cristianismo e a pregação de uma vida plena no Céu, ao constatar que o além, o nada ou o vazio, que a religião divulga como uma perfeição existente fora da Terra, faz que muitas pessoas fixem nessa direção a sua atenção, lá artificialmente encontrando um sentido para suas vidas. Porém, para o filósofo essa orientação é completamente desprovida de razão. Isso percebemos, por exemplo, em $O$ Anticristo:

Quando se coloca o centro da gravidade da vida não na vida, mas no "além" - no nada -, despoja-se a vida do seu centro de gravidade [...] tudo de benéfico, promovedor da vida, garantidor de futuro nos instintos passa a despertar suspeita. Viver de modo que já não há sentido em viver, isso torna-se o sentido da vida...(A,43).

De outra perspectiva, nós defendemos que Nietzsche atacou as religiões, principalmente o cristianismo, mas foi profundamente espiritual no sentido filosófico, ou seja, como uma pessoa que procura praticar o pensamento consciente e crítico. Nesse sentido, pode-se dizer que o ataque se referiu principalmente ao que a religiosidade tem de formalismo e padronização metódica, aos valores cristãos, com ênfase nas práticas do ideal ascético, que afasta a tradição de uma espiritualidade situada na autorreflexão: "Em toda a parte onde o espírito esteja em ação, com força e rigor, sem falseamentos, ele dispensa por completo o ideal - a expressão popular para essa abstinência é 'ateísmo' -: excetuada a sua vontade de verdade"' (GM, III,27).

A citação anterior mostra que a questão do espírito, enquanto dimensão filosófica, está presente no pensamento nietzschiano. Ressalta-se que é possível perceber no pensador a diferença entre uma espiritualidade questionadora e uma espiritualidade dogmática, presa à tradição histórica e à metafísica, sendo que é essa última que ele acusa de fraca e mentirosa, dentre outros adjetivos ainda mais duros, conforme se vê o trecho abaixo da Genealogia da moral:

[...] interpretar a história para a glória de uma razão divina, como perene 
testemunho de uma ordenação moral do mundo e de intenções morais últimas; explicar as próprias vivências como durante muito tempo fizeram os homens devotos, como se tudo fosse previdência, aviso, concebido e disposto para a salvação da alma: isso agora acabou, isso tem a consciência contra si, todas as consciências refinadas o veem como indecoroso, desonesto, como mentira, feminismo, fraqueza, covardia - devemos a este rigor, se devemos a algo, o fato de sermos bons europeus e herdeiros da mais longa e corajosa autossuperação da Europa (GM, III, 27).

É nesse contexto que Nietzsche pensa no além do homem, colocando esse além como a superação pelos indivíduos da necessidade de encontrar um sentido fora da existência, no espaço vazio. Então, é um novo ser humano, que deixou ao largo a imposição da crença num divino que está fora da vida. De outro modo, o filósofo aponta o seu projeto para a Terra, como registrou em Assim falava Zaratustra:

O super-homem [além do homem] é o sentido da terra. Que a vossa vontade diga: o super-homem [além do homem] seja o sentido da terra! Eu vos imploro, irmãos, permanecendo fiéis à terra e não acrediteis nos que vos falam de esperanças supraterrenas! São envenenadores, saibam eles ou não (ZA, "prólogo").

Essa citação de Zaratustra, para nós, enseja o seguinte entendimento: uma espiritualidade reflexiva, antidogmática, que busca o sentido da vida na existência terrena, não precisa (foge) de religiões. Também, inferimos que para Nietzsche, no que se refere à superação do ideal ascético na religião cristã, poderia estar ocorrendo uma reviravolta, por meio do transcurso do próprio processo histórico, seguindo um encaminhamento normal observado nas instituições humanas: "Todas as grandes coisas perecem por obras de si mesmas, por um ato de autossupressão: assim quer a lei da vida, a lei da necessária 'autossuperação' que há na essência da vida” (GM, III, 27).

Nietzsche não escreveu diretamente sobre o projeto de transvaloração dos valores, na Genealogia da moral, mas tratou de uma ideia conexa, que foi a transvaloração de valores dos fortes para os dos escravos, propiciada pelos judeus ${ }^{11}$. $\mathrm{O}$ projeto pensado por ele, de reviravolta dos valores morais ascéticos - então a partir desses se voltando para valores outros, os quais afirmam a vida terrena - foi tratado em livros conexos, da mesma terceira e última fase do autor, qual seja, em Além do bem e do mal e no $O$ Anticristo. Entretanto, nós entendemos que neste ponto cabe a tratar desse conceito do filósofo, na perspectiva dos valores ocidentais, pontuando que vemos semelhança com a acima citada e oportuna 'lei da necessária 'autossuperação' que há na essência da vida". Ademais, porque para nós é importante lembrar que a transvaloração de todos os valores está permeando a questão do sentido da vida, da mesma forma que o além do homem e a morte de Deus. Bem assim, porque na reflexão sobre a "lei da necessária 'autossuperação' que há na essência da vida” (GM, III, 27) depreendemos que, da mesma forma como o cristianismo estava superando o seu aspecto dogmático, com a contribuição da ciência moderna - este um tipo de conhecimento que nasceu na igreja; em seus conventos, mosteiros e seminários - ou seja, uma autossuperação por obra si mesmo, podemos inferir que também o ideal ascético seria superado no transcurso da "lei da vida".

Observando que a palavra valor é muito empregada por Nietzsche, cabe realmente frisar a importância da sua análise para o filósofo, como observa-se já no prólogo da sua obra genealógica:

Uma nova exigência se faz ouvir. Enunciemo-la, esta nova exigência: necessitamos de uma crítica dos valores morais, o próprio valor desses valores deverá ser colocado sob questão. [...] Tomava-se o valor desses "valores" como 
dado, como efetivo, como além de qualquer questionamento; até hoje não houve dúvida ou hesitação em atribuir ao "bom" valor mais elevado que ao "mau", mais elevado no sentido da promoção, utilidade, influência fecunda para o homem (não esquecendo o futuro do homem). E se o contrário fosse verdade? (GM, prólogo, $6)$.

Refletindo sobre essa citação, julgamos que chegou o momento de fazer uma ponte entre a questão dos valores e o sentido que Nietzsche oferece à psicologia. Para tanto, trazemos o registro de Scarlet Marton, que aparece no Dicionário Nietzsche, especificamente no verbete sobre a psicologia:

Ao tratar da psicologia em Humano, demasiado Humano, Nietzsche insiste na necessidade de romper com o pensar metafísico. Em vez de deduzir de princípios gerais os fenômenos morais, a psicologia deve inscrevê-los num quadro histórico, inserindo-os num tempo e num espaço. [...] Ao psicólogo tocaria questionar o valor dos valores morais, examinando as condições e circunstâncias de seu surgimento, desenvolvimento e modificações. A ele caberia relacionar os valores com as avaliações de que procedem e investigar de que valor estas partiram para criá-los. Em suma, ao psicólogo Nietzsche atribui a tarefa de avaliar as avaliações. É precisamente à crítica dos valores que Nietzsche dedica a maior parte dos seus escritos (Dicionário Nietzsche, 2016, p. 348).

Pensamos que a citação acima, relacionando valores com a psicologia, é evidente por si mesma. Então, aqui apenas vimos, inspirado nela, procurar conectar a concepção de valor com a questão do sentido da vida. Qual seja, percebemos o encaminhamento pessoal num determinado sentido como equivalente a encaminhar-se na vida com um valor. Nessa direção, uma psicologia nietzschiana (nos arriscando a assim denominar) pode ser vista como a ciência voltando-se para a mente em busca do sentido e dos valores que regem o comportamento humano.

Nesse contexto, pesquisando conexões entre as concepções de valor e de sentido, achamos interessante ver Nietzsche lembrar de Schopenhauer, de quem já estava filosoficamente afastado quando escreveu Gaia ciência (o trecho desse livro que abaixo citamos foi escrito cerca de um ano antes da Genealogia da moral), para concordar com o questionamento humano fundamental posto nessa obra, abordando a moral do cristianismo em conjunto com o sentido da vida: "Ao assim rejeitarmos a interpretação cristã e condenarmos o seu 'sentido' como uma falsificação, aparece-nos de forma terrível a questão de Schopenhauer: então a existência tem algum sentido? - essa questão que precisará de alguns séculos para simplesmente ser ouvida por inteiro e em toda a sua profundidade" (GC, 357).

Nietzsche encaminha-se para o final da Genealogia da moral se aprofundando na análise da razão para viver, fazendo isso por meio de uma relação que ele estabelece entre o sentido da vida e a vontade de verdade. Desse modo o filósofo vai destacando, sutilmente, o seu pensamento sobre a vontade de verdade (que é uma face da vontade de potência), um fenômeno observado nos homens "espirituais" - no sentido de homens amantes da filosofia, ou seja, aqueles que gostam de refletir sobre a existência. É justo na perspectiva da primazia da vontade de verdade que o filósofo escreveu: "Mas essa vontade, esse resto de ideal, é, se me acreditam, esse ideal mesmo em sua formulação mais estrita e mais espiritual, esotérico ao fim e ao cabo, despojado de todo acréscimo, e assim não tanto resto como âmago" (GM, III,27).

No nosso entendimento, Nietzsche traz uma perspectiva diferenciada da vontade de verdade, passando a colocar esse desejo humano como a vontade maior, enfim, como o grande objetivo das pessoas: o encontro de um sentido nas suas vidas. Nesse rumo o filósofo segue recolocando o tema com mais ênfase e, pouco antes de finalizar o 
penúltimo parágrafo da Genealogia da moral, apresenta a questão de forma bastante clara: "Depois que a veracidade cristã tirou uma conclusão após outra, tira enfim sua mais forte conclusão, aquela contra si mesma; mas isso ocorre quando coloca a questão: 'que significa toda a vontade de verdade?'" (GM, III,27). Nietzsche na sequência dá uma resposta para essa sua pergunta, entretanto, em forma de continuação da pergunta: "[...] que sentido teria nosso ser, senão o de que em nós essa vontade de verdade toma consciência de si mesma como problema?..." (GM, III,27).

Até a época nietzschiana - e contemporaneamente não vemos muita diferença a ciência não tinha conseguido livrar-se do ideal ascético penetrando na sua ânsia por verdade. Se o sacerdote apontava metafisicamente sua vontade para o Céu, o cientista se volta para a Terra, mas muitos ainda em busca de verdades absolutas, sem saber lidar com a imprevisibilidade dos fenômenos ou aceitar que existe o imponderável, fora do nosso alcance intelectual ou do raio que a cognição humana pode alcançar (o ser humano é idealista por natureza e muitas vezes imagina que o seu ideal é a própria verdade). Isso não quer dizer que se deve impor limites ao avanço do conhecimento. Não, mesmo porque Nietzsche nos faz compreender que é impossível barrar a vontade de verdade (uma face da vontade de potência) com limites dogmáticos (como procuram fazer os sacerdotes ascéticos). Apenas aqui nós constatamos, humildemente, que a complexidade cosmológica parece não caber no cérebro humano, mas isso não implica deixar de usufruir - conforme a capacidade, vontade e habilidade de cada pessoa - da beleza do conhecimento disponível em cada época e sempre evoluindo.

\section{Conclusão}

Chegamos ao cabo deste artigo fazendo considerações sobre o parágrafo 28 , o derradeiro da terceira e última dissertação da Genealogia da moral. Assim, junto com o filósofo aprofundamos a abordagem sobre a razão da existência e a vontade dos humanos de querer dar sentido às suas vidas.: "[...] o homem - ele não sabia justificarse, explicar, afirmar a si mesmo, ele sofria do problema do seu sentido" (GM, III,28).

Ora, como vimos o filosofar de Nietzsche nos diz que o homem vinha preenchendo o sentido da sua vida, até à época, com o ideal ascético. Ou seja, era vontade de nada, a vontade de encontrar-se com algo perfeito e que estaria fora desse mundo, era isso o que dava sentido à vida dos homens. Ademais, para realizar esse encontro contavam com a ajuda dos sacerdotes ascéticos e com os caminhos ou meios que eles indicavam.

Ressalta-se que o filósofo falou que a via do ideal ascético do cristianismo estava esgotada, tinha terminado - Deus está morto! Por outro lado, Nietzsche proclamou o advento do tempo da ciência, das luzes da modernidade e, por isso também, com essa concorrência, o sacerdote ascético não mais conseguiria oferecer sentido para a vida humana. Ou seja, o caminho estava se abrindo para os cientistas e os filósofos, enquanto fechava-se para os sacerdotes.

Entretanto, seja com sacerdotes, filósofos ou cientistas, seja como for, o ser humano deseja mesmo é encontrar explicações:

Mas seu problema não era o sofrer mesmo, e sim que lhe faltasse a resposta para o clamor da pergunta para que sofrer?'. O homem, o animal mais corajoso e mais habilidoso ao sofrimento, não nega em si o sofrer, ele o deseja, ele o procura inclusive, desde lhe que seja mostrado um sentido, um para quê no sofrimento" (GM, III,28).

É nesse contexto que nós vemos Nietzsche desenvolver o conceito do sacerdote 
ascético, aquele que chega oferecendo "facilmente" um sentido, com sua bem elaborada ideologia do além colocado no Céu: "[...] qualquer sentido é melhor do que nenhum; o ideal ascético foi até o momento, de toda maneira, o 'faute de miex' [mal menor] par excellence" (GM, III, 28).

Observamos que, nessa citação, a constatação nietzschiana é na direção de 122 perceber o ideal ascético como um mal, embora que sendo um malefício menor, diante da perspectiva de não se ter nenhum sentido na vida. Entretanto, é fundamental notar no texto o seguinte registro: foi até o momento. Ora, aqui Nietzsche percebeu o passado e o presente. Então, onde estará o futuro? No nosso entendimento é justamente agora a hora de relembrar que o filósofo refletiu sobre a transvaloração dos valores, assim como sobre o além do homem, que são concepções pensando adiante, noutro sentido para os seres humanos, esquecendo o Céu e se voltando para a Terra.

Para o filósofo, passados aproximadamente cento e trinta anos da elaboração da Genealogia da moral, o futuro é agora. Entretanto, constatamos que a sociedade humana continua dividida, mirando o sentido no Céu e (por vezes concomitantemente) se empolgando com os valores (basicamente riqueza e poder) da Terra, ademais sem se aprofundar na compreensão de si mesmo e dos valores que cultua.

Neste ponto lembramos do texto da Genealogia da moral que, no início deste artigo, pedimos que fosse guardado. Então, após discorrer sobre a terceira dissertação, acreditamos que é evidente aqui perceber que o filósofo avançou muito na direção de desvendar valores para motivar a vida humana. Todavia, nesse final, na nossa percepção é como se o pensador chegasse num determinado ponto, no qual vislumbra um obstáculo: - então, resolve frear. É assim que nós entendemos a conclusão de Nietzsche, especulando sobre a vontade de sentido:

\begin{abstract}
Mas apesar de tudo - o homem estava salvo, ele possuía um sentido, a partir de então não era mais uma folha ao vento, um brinquedo do absurdo, do semsentido, ele podia querer algo - não importando no momento para que direção, com que fim, com que meio ele queria: a vontade mesmo estava salva. Não se pode em absoluto esconder o que se expressa realmente todo esse querer que do ideal ascético recebe sua orientação: esse ódio ao que é humano, mais ainda ao que é animal, mais ao que é matéria, esse horror aos sentidos, à razão mesma, o medo da felicidade e da beleza, o anseio de afastar-se do que seja aparência, mudança, morte, devir, desejo, anseio - tudo isto significa, ousemos compreendêlo, uma vontade de nada, uma aversão à vida, uma revolta contra os mais fundamentais pressupostos da vida, mas é e continua sendo uma vontade!... E, para repetir em conclusão o que afirmei no início: o homem preferirá ainda querer o nada a nada querer... (GM, III,28).
\end{abstract}

Finalizando a partir dessa última citação, acreditamos que conseguimos referendar a nossa hipótese: seguindo a Genealogia da moral, é possível afirmar que para Nietzsche os maiores problemas enfrentados pelos seres humanos são o sentido da vida e a vontade de encontrar esse sentido. Ademais, procurando fazer nesta conclusão uma apreciação empírica sobre o projeto que o filósofo nos apresentou, o qual poderia ressignificar a questão do sentido, somos de opinião que o ser humano pouco avançou na direção da transvaloração dos valores. Bem como, no que se refere ao além do homem, observa-se que a quebra dos valores não propiciou o avanço das pessoas na direção de conhecer a si mesmas e a vida terrena, nem induziu a crítica do ideal ascético. Desse modo, a ruptura das tradições que se verificou nesse período, em vez de voltar o ser humano para as citadas concepções nietzschianas, tomou outro rumo, basicamente fixando-se na vontade de consumir a todo custo, ou em outros termos, o "ideal ascético" passou a se identificar com o intenso e ardente consumo de bens e 
serviços.

\section{REFERÊNCIAS}

BÍBLIA DE JERUSALÉM. São Paulo: Editora Paulus, 2002.

CLARK, Maudemarie. A alma de Nietzsche: uma provocativa interpretação da obra Além do bem e do mal; tradução Mário Molina. São Paulo: Cultrix, 2016.

DICIONÁRIO NIETZSCHE [editora responsável Scarlett Marton]. - São Paulo: GEN, Edições Loyola, 2016. - (Sendas \& Veredas).

MELO NETO, João Evangelista. Nietzsche: o eterno retorno do mesmo, a transvaloração dos valores e a noção de trágico. São Paulo: O autor, 2013. Tese de doutorado defendida no Departamento de Filosofia da Universidade de São Paulo.

NIETZSCHE, F. Além do Bem e do Mal. Trad. Paulo César de Sousa. São Paulo: Companhia das Letras (companhia de bolso), 2015.

NIETZSCHE, F. Aurora. Trad. Paulo César de Sousa. São Paulo: Companhia das Letras (companhia de bolso), 2016.

NIETZSCHE, F. Ecce homo. Trad. Paulo César de Sousa. São Paulo: Companhia das Letras (companhia de bolso), 2008.

NIETZSCHE, F. Genealogia da moral. Trad. Paulo César de Sousa. São Paulo: Companhia das Letras (companhia de bolso), 2009.

NIETZSCHE, F. Humano, demasiado humano. Trad. Paulo César de Sousa. São Paulo: Companhia das Letras (companhia de bolso), 2005.

NIETZSCHE, F. Humano, demasiado humano. Trad. Paulo César de Sousa. São Paulo: Companhia das Letras, 2008.

NIETZSCHE, F. O nascimento da tragédia. Trad. Paulo César de Sousa. São Paulo: Companhia das Letras, (companhia de bolso), 2017.

NIETZSCHE, F. O Anticristo. Trad. Paulo César de Sousa. São Paulo: Companhia das Letras (companhia de bolso), 2016.

\section{Notas}

10 "ascetismo", concepção que motiva o ideal ascético, está presente em várias religiões e determinadas filosofias, como a de Platão, que "se caracterizariam por assumirem um pressuposto idealista, segundo o qual o homem seria composto de duas partes, a saber, um elemento de natureza corpórea e outro de natureza espiritual. O elemento espiritual, geralmente entendido como uma substância imortal, seria o verdadeiro princípio que definiria o homem enquanto tal e, por isso, deveria ser mais valorizado e cuidado do que o corpo [...] seria concebido como uma espécie de centro diretivo do composto e, por essa razão, teria a prerrogativa e o dever de controlar e por vezes mortificar o corpo" (Dicionário Nietzsche, 2016).

2 Antinatureza é um termo nietzschiano que aparece na Genealogia da moral. Refere-se a questão sexual e faz a crítica da castidade como um valor em si.

3 Para Nietzsche os fisiologicamente deformados são os indivíduos que reprimem, dentre outros, o seu impulso sexual. O filósofo, escrevendo em 1887, afirma que na sua época esses são a maioria dos mortais e diz que são uns desgraçados.

4 Aqui podemos lembrar do movimento romântico, que criou um clima de rebeldia contra o racionalismo da Era Moderna, também se opondo ao iluminismo, com o romantismo inspirando toda uma geração de artistas. Estes foram tomados por um espírito de emoção e subjetivismo, em voga na Europa desde o final do século XIX até meados da segunda metade do século XIX.

5 Aqui se pode notar, de certa forma, Nietzsche antecipando o que hoje é conhecido como doenças psicossomáticas.

6 Nota-se uma sintonia entre essas abordagens nietzschianas e a passagem do Evangelho de João, 
9,2-4, ambos discordando de uma visão ascética. Nele Jesus é questionado sobre o que teria provocado a cegueira de um jovem. Então responde que nem foram os antepassados, ou seja, não foi uma causa externa ou superior, nem foi a própria pessoa, uma causa interna. Adicionalmente, o evangelho apenas dá a entender que sendo alguém vítima de cegueira, que seja tratado com amor, sentimento o qual, segundo Jesus, foi a obra que Deus o mandou erguer: "Seus discípulos lhe perguntaram: Rabi, quem pecou, ele ou seus pais, para que nascesse cego? Jesus respondeu: Nem ele nem seus pais pecaram, mas é para que nele sejam manifestadas as obras de Deus" (Jo, 9, 2-4, Bíblia de Jerusalém, 2002).

7 Espiritual e espírito são percebidos no nosso texto estritamente no sentido da consciência humana reflexiva, da capacidade de pensar em profundidade. Isto porque também é nessa perspectiva que consideramos estas expressões em Nietzsche: "Por '[o] espírito' (der Geist), ele entende 'pensamento consciente', especialmente a variedade filosófica" (CLARK, 2016, p.27).

8 No livro $O$ nascimento da tragédia Nietzsche analisa o espetáculo teatral em sua época clássica na Grécia. E inspirado em Apolo e Dioniso levanta sua hipótese sobre o desenvolvimento do teatro, com a introdução das formas estéticas apolíneas e das musicais dionísicas. Nesse contexto concebe a ideia da metafísica artística, que se pautaria pela estética, sendo bem mais próxima e comedida (terrena) do que a metafísica filosófica ou religiosa.

9 A expressão da língua alemã Übermensch (über significa sobre ou além; Mensch é homem) é traduzida para o português tanto como "super-homem" ou como "além do homem". Preferimos esta última expressão, principalmente para evitar o desgaste e a ambiguidade do personagem midiático.

10 Bem distante desse além do homem imaginado por Nietzsche estão os niilistas, perdidos, porque sentem-se sem apoio nesta vida, haja vista que as suas certezas sumiram durante o Século XIX. Ficaram desesperados - inclusive se percebem autorizados a auto destruição e, mesmo, a destruir o mundo. Ainda, a perda de sentido que se sente na vida torna-se um embasamento para algumas formas de "depressão" - que pode ser algo tão forte como o seu oposto: a pregação do ideal ascético.

$11 \mathrm{Na}$ Genealogia da moral vemos na primeira dissertação: "Sabe-se quem colheu a herança dessa tresvaloração [transvaloração] judaica...[...] - de que com os judeus principia a revolta dos escravos na moral: aquela rebelião que tem atrás de si dois mil anos de história, e que hoje perdemos de vista, porque - foi vitoriosa... (GM, I, 7). Com essa citação observamos o registro de uma transvaloração anterior, imposta à civilização pelos judeus. Podemos pensar que ela serve de inspiração para Nietzsche projetar outra reviravolta, que agora justamente promoveria a alteração dos valores judaico-cristãos predominantes no Ocidente. 